\title{
THE GREAT TREK AS EXODUS IN J.D. KESTELL'S AND N. HOFMEYR'S DE VOORTREKKERS OF HET DAGBOEK VAN IZAK VAN DER MERWE
}

\author{
F. Hale ${ }^{1}$
}

\begin{abstract}
Both before and after the end of the nineteenth century the Great Trek of the 1830s and 1840s was a recurrent theme in historical fiction. Not only in many of the novels written in Dutch and Afrikaans, but also in some which appeared in English, the bravery of the Voortrekkers was a pivotal theme. Often merged with this heroic motif was an identification of the Voortrekkers with the Israelites of the Old Testament. This thematic dualism reached its zenith in De Voortrekkers of Het Dagboek van Izak van der Merwe, whose authors, John Daniel Kestell en Nico Hofmeyr, both of whom were Dutch Reformed ministers, constructed the Great Trek as a post-figurative Exodus.
\end{abstract}

\section{OPSOMMING}

Voor die einde van die negentiende eeu en selfs daarna was die Groot Trek van die agtiendertiger en -veertiger jare 'n herhaaldelike tema in historiese romans. In talle van die romans wat in Nederlands en Afrikaans geskryf is, en in 'n mindere mate ook die wat in Engels verskyn het, is die dapperheid van die Voortrekkers beklemtoon. Saam met die heldhaftige beeld was nog 'n prominente tema die identifikasie van die Voortrekkers met die Israeliete van die Ou Testament. Die hoogtepunt van die tema is in De Voortrekkers of Het Dagboek van Izak van der Merwe bereik, waarin die skrywers, John Daniel Kestell en Nico Hofmeyr, altwee N.G.-predikante, die Groot Trek as 'n latere Eksodus beskou het.

\section{INTRODUCTION}

The Great Trek of the 1830s and 1840s became a recurrent theme of historical fiction before the end of the nineteenth century and remained one for several decades after 1900. Owing in no small measure to the emergence of Afrikaner nationalism before the turn of the century and its reassertion following the defeat of the two Boer republics during the Second Anglo-Boer War of 1899-1902, in many of the fictional reconstructions of this era the

1 Dr. Frederick Hale, Department of English, University of Stellenbosch, Stellenbosch, 7600, South Africa. 
emigrating Voortrekkers have been lionised as heroes who left the Colony of the Cape of Good Hope to seek freedom and economic prosperity unsullied by either indigenous Africans or British imperial officials. At times novelists and writers in other genres have also stressed to varying degrees the piety of these pioneers, portraying them as a God-fearing people whose Christian faith bore them to their goals despite all manner of tribulation. Some authors have carried this theme a step further by emphasising a tendency of some Voortrekkers to regard their migration as a re-enactment of sorts of the Exodus of the Old Testament. Perhaps nowhere has this been more prominent than in De Voortrekkers of Het Dagboek van Izak van der Merwe, which J.D. Kestell and his wife's brother, Nico Hofmeyr, both of whom were historically inclined churchmen who had been ordained in the Dutch Reformed tradition, wrote collaboratively and which was published in 1898. In the present article I shall examine how these two Afrikaner nationalists imbued their reconstruction of the Great Trek with an explicit if inconsistent theological dimension by embedding in their text a surfeit of Biblical allusions, primarily to the Exodus event but also, to a much lesser degree, other episodes in the saga of the ancient Hebrew people Israel and, briefly, even the crucifixion of Jesus Christ. Die Voortrekkers of Het Dagboek van Izak van der Merwe is thus a postfigurative narrative, one which has almost completely escaped critical analysis by both literary scholars and theologians. After briefly summarising the plot of this little-known work, I shall identify various means by which Hofmeyr and Kestell represented the Great Trek as a nineteenth-century reflection of the Exodus. The emphasis will be on the fundamentally religious nature of the Voortrekkers, as the authors in question perceived them, and relations between these migrating Boers and indigenous African peoples as the Voortrekkers seek their New Israel by leaving the Egypt of the Cape and attempting to settle in the Promised Land of Natal.

It should be underscored at the outset that Kestell and Hofmeyr did not depict the Great Trek as a seamless allegory of the Exodus. They obviously understood that the history of the emigrating Boers differed in certain key respects from that of the ancient Hebrews whom Moses led out of Egypt, not least in terms of the factors motivating each event. Furthermore, while the postfigurative Biblical elements in De Voortrekkers of Het Dagboek van Izak van der Merwe are primarily those of a new Israel manifested in Afrikanerdom, Kestell and Hofmeyr also drew occasionally on the New Testament to add further dimensions to some of their characters and the historical context of the 1830s. 


\section{THE EXODUS MOTIF IN ANTECEDENT INTERPRETATIONS OF THE GREAT TREK}

Kestell and Hofmeyr did not break entirely virgin soil by interpreting the Great Trek against the backdrop of Exodus. To a limited degree, writers of both fictional and nonfictional reconstructions of the Boer migration had used this motif before these two Dutch Reformed dominees began their collaboration on De Voortrekkers of Het Dagboek van Izak van der Merwe. One of the first to do so was their colleague Frans Lion Cachet, a Jewish Amsterdamer by birth who had converted to Christianity while a teenager and, after obtaining a theological education, arrived in Cape Town in 1860. He served as a missionary and, subsequently, highly visible parish pastor in the Nederduitse Gereformeerde Kerk, chiefly in Natal and the South African Republic, but also in the Cape, during two lengthy periods ending in 1880 and interrupted by three years in the Netherlands during the mid-1870s. A prolific and frequently controversial writer, Lion Cachet began to draft his magnum opus, an historical work of nearly 600 pages, after returning permanently to his homeland. It was published in 1882 under the title $D e$ Worstelstrijd der Transvalers. This work, completely after the First Anglo-Boer War, was a highly influential manifestation of early Afrikaner nationalism which influenced many subsequent writers, including both Kestell and Hofmeyr. Notwithstanding his Jewish heritage, Lion Cachet made relatively scant use of Biblical history when relating the story of the Afrikaners. In his detailed consideration of the Great Trek, the Exodus motif surfaces in two places. When explaining why most of the Voortrekkers chose to settle in Natal rather than following Hendrik Potgieter north of the Vaal, he declared:

En waarom zou men ook zóó ver zoeken wat in de nabijheid te vinden was? Niet naar het Noorden, niet naar Delagoa, maar naar het Zuiden moest men zijne schreden richten, naar Natal, voor de Boeren een land "Kanaän" (155).

Later in the trek, shortly before the decisive Battle of Blood River, lay preacher Sarel Cilliers and commander Andries Pretorius discuss their strategy partly in terms of their Reformed faith. An excerpt from their conversation merits citation at length to illustrate both their identity with the Israelites of the Bible and their employment of popularised covenant theology in relation to violent race relations:

"Wij moeten," zegt Cilliers, de moedige en vrome krijger, “wij moeten het van den Heere smeeken, dat Hij met ons moet gaan, zoals met Mozes en Jozua. Als de Heere niet met ons is, dan gaan 
wij gewis verloren." - "Zoals de Bijbelheiligen gedaan hebben," oordeelt Pretorius, "en den Heere een belofte doen dat, als Hij ons de overwinning over onzen vijand zal geven, wij dien dag also een sabbath, elk jaar zullen heiligen." - "Goed," antwoordt Cilliers, "maar denk er aan wat David zegt: 'Doet geloften en betaalt ze den Heere;' het is beter, dat gij niet belooft, dan uwe beloften niet houdt. God is een jaloersch God, en ik ben bevreesd dat wij den bestemden dag zullen verwaarloozen en dat met dubbele slagen worden geslagen. Enkele personen kunne hierover ook niet beslissen, wij moeten het geheele volk raad plegen" (195-196).

Perhaps with these words and a few other brief references to the Exodus and the people of ancient Israel the seeds of ethnic and religious identification were planted. But not until Kestell and Hofmeyr began to write did the spire of the Exodus motif begin to sprout notably and grow into a fully fledged metaphor which would inspire the structure and theme of a novel.

\section{VAN BALEN'S USE OF THE EXODUS MOTIF}

The virtually unknown Dutch author J. Hendrik van Balen published in 1887 what might have been the first novel about the Great Trek, De Landverbuizers, as a fictionalised account of De Worstelstrijd der Transvalers and in places relied on Lion Cachet's text to an extent that could justifiably be termed plagiarism. Though artistically very weak, Van Balen's work is relevant to our subject because it incorporates elements of the Exodus motif. As early as in the third of thirty chapters, one of the Cape farmers who is preparing to trek refers to Natal as "het beloofde land" (22). In his description of a wagon train entering Natal, Van Balen indicates that it is "eenigszins te vergelijken bij den uittocht der Israëlieten" and the destination of the Boers who have crossed the Drakensberg as "het beloofde land, het Kanaän van Zuid-Afrika, het van Natal op te zoeken" (128). The metaphor of "het beloofde land" occurs briefly three more times in $D e$ Landverbuizers $(157,158,218)$, although nowhere did Van Balen attempt to develop it thematically. The allusions are disjointed and arguably lack noteworthy rhetorical effect. What particularly underscores the weakness of his use of this theme is the absence of any consistent Moses figure from the leadership of the Voortrekkers.

Johan Frederik van Oordt, who wrote under the nom de plume "D'Arbez", created in the 1890 s and early years of the twentieth century a long series of Dutch language novels about topics in South African history chiefly for young South Africans. One of the first volumes, David Malan, which was published in 1894, is a fictional reconstruction of the Great Trek. Van Oordt gave Cilliers a relatively great deal of space and described him in 
heroic terms. This lay preacher voices the New Israel motif. Preparing for battle, he assures his fellow Voortrekkers that "God, de God van Israël sta ons thans bij" (128), and after they emerge victorious the latter-day patriarch Cilliers delivers "een dankgebed op tot den God van Abraham, van Izaäk en van Jakob” (126). Subsequently Van Oordt ascribed Levitical characteristics to this spiritual and military leader:

In krachtige taal smeekte Charel Cilliers, zoals de Hoogepriester van Israël eens deed, den Almachtigen Scheeper van Hemel en Aarde, om de zonden van dit Zijn volk te vergeven, en $\mathrm{Zijn}$ toorn niet op het te doen nederdalen (139).

The American Presbyterian missionary Daniel Lindley, who assists the Voortrekkers, reinforces their identification with the Hebrews of the Bible during a service he arranges for them, especially in

eene hartroerende toespraak tot de Boeren hield, en hen wees op het lot der Israëlieten in de woestijn, dat hij met het hunne vergeleek, voornamelijk daarop wijzende, dat God Zijne getrouwen nooit verlaat maar hen steeds op de meest wonderbare wijze redt (141).

\section{KESTELL AND HOFMEYR AS EXPONENTS OF AFRIKANER RELIGIOUS NATIONALISM}

The Biblical motifs as the essence of a religio-nationalistic interpretation of the Great Trek in De Voortrekkers of Het Dagboek van Izak van der Merwe were a natural consequence of the two authors' familial, spiritual, and educational backgrounds. Both men's early careers and ethnic attitudes were shaped in the crucible of Afrikaner nationalism. During the 1890s Kestell had already travelled far along a road which would eventually lead him to positions of prominence in both Dutch Reformed and Afrikaner nationalist circles. His pedigree did not suggest this would be the case. Kestell's English father, a native of Devonshire, was among the 1820 Settlers in the Eastern Cape who moved to Natal in the 1840s and joined the Dutch Reformed Church in Pietermaritzburg. There this English immigrant married an Afrikaans woman, Dorothea Louisa Weyer, who gave birth to John Daniel in 1854 but died less than five years later. Young Kestell's stepmother was also Afrikaans. He attended secondary school at Stellenbosch Gymnasium and subsequently studied theology at that city's Kweekschool, from which he graduated in 1880, and briefly the University of Utrecht. In Stellenbosch Kestell had studied under Professor N.J. Hofmeyr, whose biography he would eventually write and whose eldest daughter Geertruida Anna he married in 1882. The young graduate accepted pastoral calls to Du Toitspan in 1881 and the 
following year to Kimberley. In 1894 Kestell was inducted into the ministry at Harrismith, whose commando he served as a chaplain during the Second Anglo-Boer War. In the wake of the defeat of the Boer republics, he was in 1909 one of the founding members of the Zuid-Afrikaansche Akademie voor Taal, Letterkunde en Kunst (subsequently the Suid-Afrikaanse Akademie vir Wetenskap en Kuns). Increasingly well known as a theological writer, Kestell became editor of De Kerkbode in 1919. By then he was already heading a commission to translate the Bible into Afrikaans. During the latter half of the 1930s Kestell played a prominent part in commemorating the centenary of the Great Trek, another high water mark in the unfolding of Afrikaner nationalism (Nienaber 1946:124-128).

Nico Hofmeyr (1860-1932) was the third son of Professor N.J. Hofmeyr and thus a brother-in-law of Kestell when the two collaborated in writing De Voortrekkers of Het Dagboek van Izak van der Merwe. Born in Stellenbosch, the younger Hofmeyr studied at both the Kweekschool and Victoria College (the antecedent institution of the University of Stellenbosch), where he received a Bachelor of Arts in 1878. After touring Europe, he became minister of the Dutch Reformed Church at Warrenton in 1885, a post he demitted in 1891 to become the editor of De Express in Bloemfontein. Simultaneously with his journalistic career, Hofmeyr turned to the writing of paedagogial history, as we shall see shortly. Shortly after the Jameson Raid of 1895 he published his De Afrikaner-Boer en de Jameson-inval. Hofmeyr's career as an amateur historian led to a lectureship in history at the Staats-gymnasium in Pretoria. It was while serving in this capacity that he co-operated with his brother-in-law to write their novel (Nienaber 1972: 326-327).

\section{1893 NATIONALISTIC EMPHASES AS A PRELUDE TO DE VOORTREKKERS OF HET $D A G B O E K$}

In a series of lectures which he delivered in 1893 to a Christian youth organisation in Kimberley, Kestell interpreted the Great Trek in an unabashedly nationalist vein. Relying on inter alia Frans Lion Cachet's magnum opus of 1882, De Worstelstrijd der Transvalers, he traced how the aggrieved Boers had heroically struggled against natural and human foes to find a new home first in Natal and later in the Transvaal and the Orange Free State. It must be emphasised, however, that Kestell did not at use this lecture series to impose an Exodus interpretation on the Boer migration. His primary emphasis in depicting the Voortrekkers was clearly on their quest for freedom 
from British colonial rule. Indeed, other than a brief reference to the reverence in which the Voortrekkers held the Bible (Kestell 1893:30), Kestell's lectures contained surprisingly little about the religious life of the these pioneers or the theological significance of their migration.

Writing the same year, Hofmeyr cast his remarks about the Voortrekkers and the Great Trek in a much more explicitly religious mould in which the identity of the Great Trek as a nineteenth-century reflection of the Exodus could have hardly been more emphatic. Hofmeyr had demitted his ministry nearly three years earlier in order to assume the editorship of De Express in Bloemfontein but remained a prominent member of the Nederduitse Gereformeerde Kerk. When Dr. John Brebner, the Scottish immigrant superintendent of education in the Orange Free State, commissioned the gifted young intellectual in 1893 to prepare a historical reader in Dutch, Hofmeyr responded in accord with the waxing mood of Afrikaner nationalism and promptly produced the first edition of his Kijkjes in Onze Geschiedenis, which would eventually go through many printings and circulate in more than 100,000 copies. Nearly every page of this textbook vividly reflects its author's commitment to nurturing that cause. Writing in an ethnocentric vein in which he stressed the deeds of his own and his juvenile readers' ancestors, Hofmeyr lost no time in setting a tone of Netherlandic and Afrikaner heroism and victimisation in the opening sentence of his Preface. "Heeft vader of moeder u al van Jan van Riebeek of Andries Pretorius, van Slachtersnek of Dingaansdag verteld?" he asked. Hofmeyr proceeded to cast himself into a latter-day Mosaic rôle by exhorting his readers to look up Exodus 12:26-27, but nevertheless quoting Moses's injunction regarding preserving the memory of the Passover in extenso:

En het zal geschieden, wanneer uwe kinderen tot $\mathrm{u}$ zullen zeggen: Wat hebt gij daar voor eene dienst? Zoo zult gij zeggen: Dit is den Heere een Paaschoffer, die voor de huizen der kinderen Israëls voorbijging in Egypte, toen Hij de Egyptenaren sloeg, en onze huizen bevrijdde.

Apparently Hofmeyr saw no discrepancy in applying this injunction to the recent history of his own ethnic group, perhaps perceiving in the latter a clear manifestation of the spirit of the Exodus. Indeed, in arguing for the importance of national history as an overarching priority for youth, he asserted, "Ja, 't is een heilige plicht, die u opgelegd is, kinderen, om die geschiedenis van uw land en volk te leeren". In one of his most revealing statements, Hofmeyr explained that the quoted Mosaic text underscored "hoe nauw godsdienst en geschiedenis aan elkander verbonden zijn”. Yet it was not merely a religious duty, he stressed, to read national history, but also a matter of instilling ethnic pride: 
Uw volk zult gij alsdan al meer lief krijgen, en uw God zult gij al meer danken, dat gij uit zulk een vroom en ernstig geschlacht geboren zijt (Hofmeyr 1893:1-2).

There was nothing subtle about Hofmeyr's endeavours to inculcate in the minds of young Afrikaners an identification of the Voortrekkers as heroic models and of the Great Trek as a new Exodus. He declared:

Geen wonder, dat er op die wijze, in zulk een oefenschool dan ook helden onder het voorgeschlacht gevormd werden, en mannen zooals Hendrik Potgieter, Gerrit Maritz, Pieter Uys, Karel Landman, Sarel Cilliers, Pieter Retief, Andries Pretorius onder ons volk opstonden. In één woord, de geschiedenis van den grooten Trek is die geschiedenis van ons heldentijdperk.

These champions were not merely ethnic but also religious figures modelled after Penteteuchal types:

God wekte de Mozessen, Aaron's Jozua’s, Caleb's en Miriam’s op, die ons volk noodig had in zijn uittocht uit de Kolonie naar de onbekende deelen van Zuid-Afrika.

Hofmeyr then briefly adduced a New Testament allusion in broaching an element of Christian martyrdom:

Veel hebben zij moeten lijden, zwaar was hun kruis, maar groot was ook hun geloof en moed. Hunne namen zijn voor altoos in het Afrikanerhart gegrift en hunne daden met gulden letters in onze geschiedrollen opgeteekend (68).

\section{NARRATIVE STRUCTURE AND PLOT SUMMARY}

The narrative structure and plot of De Voortrekkers of Het Dagboek van Izak van der Merwe bear a striking resemblance to those of David Malan, which Johan Frederik van Oordt, writing under the pseudonym "D'Arbez", had published as an early volume in his series, the Zuid-Afrikaansche HistorieBibliotheek in 1894. In brief, like that antecedent adolescent novel, the one by Kestell and Hofmeyr is a weaving together of a fictionalised general history of the Great Trek, beginning in the Eastern Cape and ending shortly after the Battle of Blood River, and a melodramatic subplot rotating around the romantic relationship of two young participants in the migration. Remarkably enough, the young protagonist is present at most critical points in the history of the Great Trek and repeatedly distinguishes himself through his bravery and other commendable attributes. This adds a didactic, axio- 
logical dimension to the novel; clearly Izak van der Merwe is a heroic model to be emulated by Afrikaners of the 1890s. De Voortrekkers of Het Dagboek van Izak van der Merwe differs, however, in that it employs a first-person narrator. To be sure, the title is misleading. One need not read many pages of this book before realising that it is not a contemporary account written by a teenaged farm boy but a retrospective one penned from a theologically informed point of view. The underlying narratorial premise is thus essentially implausible.

The plot begins on Christmas Eve in 1834 when the Van der Merwe family, who farm at an undisclosed place in the Eastern Cape, discover that several of their neighbours have been attacked by Xhosas in the so-called "Kaffer Wars". Shortly thereafter, this family, together with others in the area, learn of other farmers' plans to quit the region and re-establish themselves elsewhere, preferably in Natal. Discussions preceding the Van der Merwes' and their neighbours' decision to join the migration allow Kestell and Hofmeyr to voice what by the 1890s were regarded in Afrikaans circles as the essential causes of the Great Trek, especially such insufferable conditions as the ineffectiveness of the British colonial administration to protect them from indigenous Africans and the economically devastating terms under which slavery had recently been abolished. They sell their farms for a pittance, pack their wagons, and join the trek led by Hendrik Potgieter.

Almost immediately the trekkers encounter hostile blacks, however, and violently strained race relations remain the principal narrative thread in the historical narrative. Kestell and Hofmeyr relate how they successfully - though not without incurring losses - fend off a major Matabele assault at Vechtkop (63) and how the seemingly invincible Hendrik Potgieter leads an effective punitive expedition against that tribe (125). As part of their initial contract with Dingaan, a group of prominent Voortrekkers defeat Sikonyella, who has stolen large numbers of the Zulu monarch's cattle (126). Culminating their protracted struggle to gain a foothold in the Promised Land of Natal, Andries Pretorius, Sarel Celliers, and other Voortrekkers defeat a numerically vastly superior Zulu force at what would subsequently be called the Battle of Blood River. Before doing so, these Christian warriors enter into their special covenant with God (151ff.). In a very general sense, these ultimately conflicts parallel the struggle of the Mosaic Hebrews in their conquest of Canaan. 


\section{AFRIKANER RELIGIOSITY}

In this novel Hofmeyr and Kestell emphasise repeatedly the underlying religious nature of the Voortrekkers, a point they begin to underscore in the first paragraph of their text. There, Boers on the Eastern Cape are diligently preparing to celebrate Christmas in 1834. Before the Van der Merwes embark on the Great Trek, they have regular family devotions (buisgodsdienst) at which the patriarch of the clan reads from Genesis 12 and those present sing from the Psalter (35-36). Moreover, the narrator has vivid recollections of celebrating the Lord's Supper quarterly in church (8). Familial spirituality is not contingent on geographical stability but continues en route to Natal. Kestell and Hofmeyr underscore the piety of Sarel Cilliers but also point out that his devotional life meshes well with that of other Voortrekkers. They thus pray together while under attack early in the trek (67), and when an army of Boers goes forth to punish the Zulus after the massacre of Piet Retief and his company at Dingaan's kraal, Cilliers accompanies them and conducts worship every evening (190f.). It is as a worshipping community that these pioneers are seen to be acting on God's behalf, not merely in terms of human vengeance, and as a people of faith they make their vow before the Battle of Blood River (191-194). This identification of the Afrikaners in question as a generally religious people is essential to the Biblical identity which Hofmeyr and Kestell establish for them as they proceed through the wilderness as a faithful, covenant people seeking their divine destiny in a promised land. Without this foundation, the superstructure of Biblical allusions which the two authors construct would be insecure.

To be sure, the Voortrekkers of this novel do not place their imprimatur on everything that smacks of Christianity. They are quite capable of subordinating their Christian identity to racial and political concerns. Perhaps this is most vividly exhibited in Kestell's and Hofmeyr's brief discussion of Anglophone missionaries, some of whom repeatedly play villainous historical rôles in early Dutch and Afrikaans fictional and nonfictional reconstructions of the Great Trek. In the second chapter the narrator takes to task representatives of the London Missionary Society for lending rhetorical support to non-whites in the Cape, especially "Dr. [John] Philip en andere dweepzieke zendelingen" for advocating in the United Kingdom the cause of the "arme, verdrukte, mishandelde, bestolene Kaffers" (18). Their pleas on behalf of the indigenous peoples of the Cape were particularly irksome, of course, because they inevitably cast aspersions on the morality of the Afrikaners, and the resulting resentment comes clearly to the fore in $D e$ Voortrekkers. This is particularly apparent when the Van der Merwes and their neighbours discuss the political and administrative consequences in 
the Cape of the missionaries' defence of the non-whites. The narrator sums this up as a prime factor in precipitating the Great Trek:

Hoe zwaar, hoe bitter zwaar het ook was om de geliefde erve onzer vaderen en graven onzer dierbaren vaarwel te zeggen, wij werden daartoe door de dwaze politiek der Imperiale Regeering gedreven (18-19).

By contrast, missionaries who assist the Voortrekkers en route to Natal or in Zululand fare well under Kestell's and Hofmeyr's pens. James Archbell, for example, helps them at Thaba 'Nchu after the disastrous Matabele attack on Potgieter's trek (75), and the English missionary Francis Owen, working at Dingaan's royal kraal, despite being English, is favourably depicted because he facilitates negotiations between Piet Retief and the Zulu monarch (111).

\section{IDENTIFYING WITH THE ISRAELITES OF THE TORAH}

In places, the identity of the Voortrekkers with the Hebrews of the Exodus is so explicit and self-conscious as to rule out all subtlety about this pivotal dimension in the novel. This, too, is something which Kestell and Hofmeyr establish early on. At the close of the first chapter, they explicitly compare the prospective Boer migrants with the enslaved Hebrews in Egypt, partly by means of Passover elements. "In bitterheid des geesten en gedurige vreeze aten wij dus de lekkernijen van den Kerstdag, gelijk de kinderen Israëls hun paaschlam met bittere saus mengden", recalls Izak van der Merwe of their Christmas dinner immediately after the lethal Xhosa attack on their neighbours (13). The rough-hewn but at times sagacious Hans Swarts voices the identity of the group with the people of the Exodus upon hearing of Sir Andries Stockenström's efforts to prevent disgruntled Afrikaners from leaving the Cape Colony. "Zooveel te beter voor ons", declares this prospective trekker, "maar als Farao ons mocht achterna zetten, zal hij gewis in de Roode, ik bedoel Oranje Rivier omkomen" (31).

\section{DEMONISING THE AFRICANS}

In Kestell's and Hofmeyr's historical pageant, the casting of the indigenous Africans as the Canaanite foes of the trekking New Israel is facilitated by the depiction of the former as an inferior race. Young Van der Merwe underscores this point as a corollary to his description of Hendrik Potgieter as both a natural leader of and a man on a par with his fellow Voortrekkers. He explains: 
Wij Boeren erkennen geen hoogen en lageren stand in ons midden; elke Boer is een man en een broeder, hetzij rijk of arm, hetzij goed of slecht.

But this doctrine of social equality does not extend beyond the pale of the volk. The other side of the coin merits equal emphasis:

Geen gelijkheid tusschen blanken en zwarten, de grootste gelijkheid onder blanken en blanken - dat is onze leuze altijd geweest (37).

All of the African tribes with whom the Voortrekkers interact are portrayed negatively, though some significantly more so than others. Relations with the Matabeles do not extend beyond armed conflict. Before these blacks attack the wagons, Hannie suggests to Schalk van der Merwe that their chief, Moselekatze, "meer op een duivel dan op een mensch moest gelijken", a fear to which he replies negatively, stressing that he has heard that this particular Matabele "een vriendelijk gelaat heeft en dat zijne stem zacht als die eener vrouw is!” (65). Unconvinced, Hannie retorts that Moselekatze is thus

vriendelijk en toch zoo wreed, zacht van stem en toch zoo bloeddorstig en onmenschelijk - wie kan schijn en werkelijkheid van elkander in deze wereld onderscheiden? (65).

Moselekatze's subjects fare no better. Kestell and Hofmeyr describe how "de wilden sloegen hun schilden met assagaaien, [en] riepen hun geduchten oorlogskreet uit" (66) and, two pages later, call these warring Africans "de woste vijand" and "zwaarte duivelen" (68). They have nothing positive to say about the Matabeles and, with regard to Moselekatze, note with relief that "de onbeschofte wreedaard" disregards Piet Retief's peace initiative and consequently is driven with his ethnic fellows northward across the Limpopo (95-96).

The depiction of the Zulus is only marginally more complimentary, and the few positive words Kestell and Hofmeyr include about them serve in their rhetorical scheme to accentuate the heroic virtues of the Voortrekkers and underscore the motif of the latter as a chosen people who proceed under divine guidance to the occupation of their new homeland. While sitting with his children and other migrants around a campfire en route to the Drakensberg, the even-tempered Schalk van der Merwe warns inquisitive youth that "de Kaffers der Kaapkolonie zijn als lammeren, vergeleken bij de Zulu's" and exclaims, "God verhoede dat wij met die wreede natie in botsing komen!" The senior van der Merwe then relates how during the conquests 
of Shaka (whom he calls "meer duivel dan mensch" [57]) the Zulus destroyed their enemies:

In de stilte des nachts werden hunne kralen bestormd en mannen, vrouwen en kinderen vermoord,....... behalve de schoonste jonge meisjes, die naar den koning gevoerd, en de jonge mannen, die bij de Zulu-legers ingelijfd werden (59).

Yet Hofmeyr and Kestell take pains to point out that some members of that tribe treat the Voortrekkers civilly. The narrator reports that when the Retief party initially enteres Zululand,

de Kaffers, die wij aantroffen, stapten er henen als koningen zoo onafhankelijk en toch waren zij uiterst vriendelijk jegens ons.

These indigenes welcome the Voortrekkers with beer in a spirit of hospitality. This reception leads young Van der Merwe to draw an ethnic comparison: "Het onderscheid tusschen den beleefden, waardigen Zulu en den onbeschoften, lagen Xosa trof ons allen terstond" (107-108).

This initially warm reception does not, however, foreshadow either harmonious relations between the Zulus and the Voortrekkers or a positive depiction of the former. Indeed, upon their initial arrival at Dingaan's kraal, they discover that the Zulus there are "een geoefend leger ... uitgenomen de zwarte, bloeddorstige gelaatstrekken en vreemde kleedij en wapens". Retief assures an associate of "het gevreesde opperhoofd" and "de sluwe Kaffer" Dingaan, "Gij zijt inderdaad een krijgshaftig volk" (109, 111, 113). The narrator also describes the royal wives who dance for the Voortrekkers on this occasion as a repulsive lot:

Haar zang was zonder schoonheid, hare bewegingen allesbehalve sierlijk; met moeite slechts kon ik mijne neiging om in luiden lach uit te schateren bedwingen! (117-118).

Against the backdrop of this negative if piecemeal group portrayal, the eventual brutality of the Zulu resistance to the Voortrekkers' occupation of their Promised Land comes as no great surprise. Kestell and Hofmeyr nevertheless provide additional foreshadowing bridges. When, during Retief's first visit to the dastardly Dingaan's royal kraal, the Zulu monarch informs his visitors, "Wij hebben alle zwarte volkeren aan deze zijde van de Drakensbergen opgegeten" and adds the marginally cryptic warning, "Er zijn nog andere volkeren, die wij wenschen op te eten!", Izak van der Merwe shares with two of his Afrikaans friends his premonition that the Voortrekkers entering Natal are among those on Dingaan's menu (113-114). Not 
long thereafter, the realistically pessimistic Hans Swarts, again serving as a counterweight to the naïveté of Retief, warns him of impending danger:

Ik ken de Kaffers beter dan u ze kent. Onder Kaffers ben ik opgegroeid, en als ik éen ding versta, dan is het de geaardheid van die schelmen. Zij zijn door en door valsch en onvertrouwbaar (130).

\section{JUSTIFYING THE CONQUEST AND OCCUPATION OF INDIGENOUS LANDS}

As indicated in the introduction to the present article, De Voortrekkers of Het Dagboek van Izak van der Merwe is not an allegorical re-enactment of Exodus, but rather a history of the Great Trek in which that event is interpreted as analogous episode in the history of a God-fearing people. The limits of this analogy perhaps become most apparent in Kestell's and Hofmeyr's apologia for the Voortrekkers' occupation of what would become the Orange Free State, Natal, and the South African Republic. Despite all their Biblical language and self-conscious establishing of parallels between the Great Trek and the conquest of Canaan by the Hebrews following their liberation from slavery in Egypt, these two Dutch Reformed authors emphasise that the Boers' ownership of vast tracts of land beyond the Great River sprang from worldly contracts, not from a covenant with God. The terms of the Voortrekkers' campaign against the Matabeles on behalf of the Betuangs under Chief Makwana provided the first right of ownership. Potgieter had concluded a deal with that ruler

waarbij het land tusschen de Vet- en Vaalrivieren aan ons gegeven werd, mits wij de Betuangs tegen hun vijand in het noorden beschermden.

In one of their most obvious didactic authorial intrusions, Kestell and Hofmeyr insist regarding the Voortrekkers that

hun land werd nie geroofd, maar geruild; zij werden nimmer door ons uitgeroeid, maar gered! Wij verlosten de arme, vervolgde, verhongerende stammen eerst van Moselekatze, en daarna van Dingaan. Wee hun, die ons belasteren, door de Boeren "roovers en verdelgers der naturellen" te noemen! (61).

Victory over the Matabeles places not only much of the subsequent Orange Free State into the hands of the Voortrekkers, but also vast areas of the Transvaal. After pressuring Moselekatze and his followers to migrate north of the Limpopo, "Potgieter heeft ook het geheele land, door de Matabelen verlaten, als het gebied der Voortrekkers geproclameerd" (125). 
With regard to the acquisition of Natal, Kestell and Hofmeyr do not sing a consistent tune. Initially, this is presented as a business transaction. "Ik ben gewillig voor het land te betalen", announces Retief during his earliest negotiations at Dingaan's kraal. This offer is never formalised, however; instead, after the Zulu monarch complains about the loss of his cattle and demands that Retief assist in their recovery, seeking to entice him with a counteroffer:

Breng mij het vee terug en ik zal u gelooven. Verder beloof ik u dit: als gij mij mijn vee weer laat zien, dan geef ik u het geheele land tusschen de Tugela en de Umzimvubu present.

Retief accepts using words which confirm these terms:

Uw vee breng ik u terug, maar onder de uitdrukkelijke verstandhouding tusschen ons, dat mijn werk als betaling voor het land tusschen de Tugela en de Umzimvubu zal gelden.

Dingaan, to be sure, imposes another condition - the capture, dead or alive, of Sikonyella, who he believes has stolen his livestock. Retief makes no commitment regarding this matter (121-122). When the massacre of the Boer commandant and his entourage on their return to Dingaan's kraal and the subsequent discovery of a deed of cession on Retief's corpse make it clear that the Zulu monarch had not intended to respect his contract, Hofmeyr and Kestell abandon the argument that Natal was acquired by a bilateral agreement:

Neen! de Boer grondt zijn eigendomsrecht op Natal geenszins op dat stukje papier: hij heeft een veel dieper, breeder en hechter fondament om op te bouwen. Toen wij in Natal kwamen, was het land woest en ledig, geheel en al "uitgemoord"; verraderlijk en onschuldig werden wij door Dingaan aangevallen, toen wij er vreedzaam in gingen wonen; met Gods hulp straften wij den valschen verrader en dwingeland, en als overwinnaars werd Natal onze wettige buit (203).

\section{CONCLUSION}

The Exodus motif would become a recurrent theme in subsequent historical fiction about the Great Trek, especially in novels written in Dutch and Afrikaans. In none of these later works, however, were its place and function nearly as prominent as under the theologically informed pens of Kestell and Hofmeyr. Played in another key, it also reverberates in Stuart Cloete's highly controversial work of 1937, Turning Wheels, where an imperious Voortrekker leader who appears to have been inspired by Hendrik Potgieter regards himself as both a Mosaic and an Abrahamic figure as he 
guides his fellow migrants north and east. Curiously enough, when Hofmeyr reworked De Voortrekkers of Het Dagboek van Izak van der Merwe into an Afrikaans novel titled Fanie, which was published in 1925, this erstwhile dominee sharply reduced the number of Biblical allusions which had arguably weighed too heavily on the original text and also reduced the Exodus motif, which, however, remains fairly prominent in that work. Perhaps the greatest significance of the novel which Kestell and Hofmeyr created lies in its blatant and emblematic interweaving of history, religion, and nationalism on the eve of the Second Anglo-Boer War, reflecting a mind-set which would survive that conflict and provide much of the attitudinal foundation on which such Afrikaner nationalists as Gustav Preller would construct their version of their ethnic group's history.

\section{BIBLIOGRAPHY}

\section{D'ARBEZ N D}

David Malan. Een verhaal uit den Grooten Trek. Amsterdam and Cape Town: HollandschAfrikaansche Uitgevers-Maatschappij.

\section{HaLe $\mathrm{F}$}

2000. The fountain-head of Dutch fictional reconstructions of the Great Trek: J. Hendrik van Balen's De Landverbuizers. Tydskrif vir Nederlands en Afrikaans 7: 56-73.

\section{HOFMEYR N}

1893. Kijkjes in de geschiedenis van Zuid-Afrika. Een leesboek voor school en huisgezin. Amsterdam en Kaapstad: Jacques Dusseau \& Co.

1925. Fanie. Kaapstad, Stellenbosch en Bloemfontein: Nasionale Pers Beperk.

KeSTELL J D

1881. The struggle for freedom; or the rebellion of Slagters Nek. London: Wyman \& Sons. 1893. De Voortrekkers. Eene reeks van voorlezingen, gehouden in verband med de Kimberleysche Christ. Jongelings-Vereeniging. Paarl: D.F. du Toit.

LION CACHET F

1882. De worstelstrijd der Transvalers. Amsterdam: J.H. Kruyt.

NiENABER P J

1946. Dr. J.D. Kestell. Vader van die Reddingsdaad. Bloemfontein, Kaapstad en Port Elizabeth: Nasionale Pers Beperk. 
1972. Hofmeyr, Nicolaas. In: W.J. de Kock (red.), Suid-Afrikaanse Biografiese Woordeboek, I. Pretoria: Nasionale Raad vir Sosiale Navorsing, 441-443.

\section{Nienaber, J D}

1968. Kestell, John Daniel. In: W.J. de Kock (red.), Suid-Afrikaanse Biografiese Woordeboek, II. Pretoria: Raad vir Geesteswetenskapelike Navorsing, 326-327.

\section{VAN BALEN J H}

1887. De landverbuizers, de Groote "Trek" der Kaapsche Boeren 1836-1840. Tiel: H.C.A. Campagne \& Zoon.

Keywords

South African history

Voortrekkers

Great Trek

J. D. Kestell

N. Hofmeyr

Exodus
Trefwoorde

Suid-Afrikaanse geskiedenis

Voortrekkers

Groot Trek

J. D. Kestell

N. Hofmeyr

Eksodus 